\title{
Processos de subjetivação no Clube da Luta
}

Fernanda Luzia Lunkes

Dissertação de Mestrado, 2007

Universidade Estadual de Maringá - UEM

Centro de Ciências Humanas, Letras e Artes

Programa de Pós-Graduação em Letras

Nossa pesquisa, intitulada $O(s)$ sujeito(s) no Clube da Luta: o Outro no mesmo, objetiva explicitar os processos de subjetivação no contexto do filme Clube da Luta (EUA, 1999, direção de David Fincher). Para a Análise de Discurso (Pêcheux), a homogeneidade do sujeito é um efeito ideológico e uma das “surpresas” do filme está na descoberta de que os dois personagens, Jack e Tyler, são a mesma pessoa. E nesse sentido, o corpo se materializa. Tomando o verbal e o não verbal enquanto discurso, empreendemos nossos recortes de acordo com a nossa pergunta, considerando que o corpo perpassa toda a narrativa fílmica enquanto lugar de repetição e de resistência: se há a interpelação constante de um imaginário, o corpo pode ser um lugar de inscrição desse imaginário? Descrevendo as regularidades discursivas de Jack e Tyler, procuramos mostrar a construção heterogênea do sujeito, as coerções que o indivíduo sofre e como isso se dá no simbólico e no corpo. Compreendemos que nosso sujeito no filme vai se constituindo por diferentes processos de identificação no corpo: na primeira fase ele traz o seu Outro através da regularidade em nomear grifes como metáfora do corpo aceito enquanto seu nome, uma das “marcas” oficiais do sujeito na História, é silenciado; na segunda se auto-denomina "alguma coisa" de Jack, metaforizando-se tanto pelo lado biológico quanto pelo emocional; na terceira, através de Tyler, ele traz o seu Outro no discurso de resistência e pelo corpo com outras marcas. Para nós, o título Clube da Luta organiza uma paráfrase discursiva em que "luta” significa "luta física”, apontando também para a polissemia: a “luta ideológica”. E o corpo inscrevendo ambas discursividades.

Palavras-chave: Discurso. Sujeito. Corpo. 